\title{
PENGARUHPEMBERIAN TABLET FE TERHADAP PERUBAHAN KADAR HB PADAREMAJAPUTRI DI PONDOKPESANTRENMIFTAHULKHOERTASIKMALAYATAHUN 2018
}

\author{
Oleh : \\ Emut Haolatul Mutmainnah ${ }^{1}$ Siti Saadah Mardiah $^{2}$, Endang Astiriyani ${ }^{3}$
}

\section{A. ABSTRAK}

Anemia merupakan salah satu masalah kesehatan di seluruh dunia terutama negara berkembang yang diperkirakan $30 \%$ penduduk dunia menderita anemia. Remaja putri memiliki risiko sepuluh kali lebih besar untuk menderita anemia dibandingkan dengan remaja putra. Hasil studi pendahuluan yang dilakukan di Pondok Pesantren Miftahul Khoer Tasikmalaya pada remaja putri pada usia 14-20 tahun dari 10 orang remaja setelah dilakukan cek kadar Hb didapatkan sebanyak 8 orang (80\%) memiliki kadar $\mathrm{Hb}<12 \mathrm{gr} / \mathrm{dl}$ dan sebanyak 2 orang (20\%) memiliki kadar $\mathrm{Hb}>12 \mathrm{gr} / \mathrm{dl}$. Tujuan penelitian adalah untuk mengetahui pengaruh pemberian tablet Fe terhadap perubahan kadar Hb pada remaja putri.

Metode penelitian yang digunakan adalah eksperimen dengan jenis penelitian pre eksperimen denganrancangan Pretest-Posstest. Populasi dalam penelitian ini adalah remaja putri usia 14-20 tahun yang mengalami anemia ringan sebanyak 28 orang, teknik pengambilan sampel menggunakan teknik Total Sampling yaitu sebanyak 28 orang.

Hasil penelitian menunjukkan bahwa remaja putri sebelum dilakukan pemberian tablet Fe seluruhnya mengalami anemia ringan yaitu 28 orang (100\%), sedangkan sesudah dilakukan pemberian tablet Fe remaja putri tidak mengalami anemia yaitu sebanyak 27 orang (96,4\%). Hasil uji perubahan kadar Hb diperoleh nilai t-hitung sebesar -13,031 dengan tingkat signifikansi ( $\left.\rho_{\text {value }}\right)$ sebesar 0,000, yang berarti bahwa ada pengaruh pemberian tablet Fe terhadap perubahan kadar Hb pada remaja putri.

Hendaknya petugas kesehatan dapat memberikan pendidikan kesehatan dan sosialisasi Fe pada remaja mengenai anemia serta melakukan pendekatan dengan pihak pesantren untuk pemantauan kadar Hb pada remaja putri setiap 6 bulan sekali.

\section{Kata Kunci : Tablet Fe, Kadar Hb, remaja putri}




\section{B. LATARBELAKANG}

Anemia merupakan salah satu masalah kesehatan di seluruh dunia terutama negara berkembang yang diperkirakan $30 \%$ penduduk dunia menderita anemia. Anemia banyak terjadi pada masyarakat terutama pada remaja dan ibu hamil. Anemia pada remaja putri sampai saat ini masih cukup tinggi, menurut World Health Organization (WHO) (2013), prevalensi anemia dunia berkisar $40-88 \%$. Jumlah penduduk usia remaja (10-19 tahun) di Indonesia sebesar $26,2 \%$ yang terdiri dari 50,9\% laki-laki dan 49,1\% perempuan (Kemenkes RI, 2013).

Data hasil Riskesdas tahun 2013, prevalensi anemia di Indonesia yaitu 21,7\% dengan penderita anemia berumur 5-14 tahun sebesar $26,4 \%$ dan $18,4 \%$ penderita berumur 15-24 tahun (Kemenkes RI, 2014). Data Survei Kesehatan Rumah Tangga (SKRT) tahun 2012 menyatakan bahwa prevalensi anemia pada balita sebesar $40,5 \%$, ibu hamil sebesar $50,5 \%$, ibu nifas sebesar $45,1 \%$, remaja putri usia 10-18 tahun sebesar $57,1 \%$ dan usia 19-45 tahun sebesar $39,5 \%$. Wanita mempunyai risiko terkena anemia paling tinggi terutama pada remaja putri (Kemenkes RI, 2013).

Remaja merupakan tahap dimana seseorang mengalami sebuah masa transisi menuju dewasa. Remaja adalah tahap umur yang datang setelah masa kanak-kanak berakhir, ditandai oleh pertumbuhan fisik yang cepat. Remaja dalam masyarakat dikenal dengan berbagai istilah yang menunjukkan kelompok umur yang tidak termasuk kanak-kanak tetapi bukan pula dewasa. Pertumbuhan remaja yang pesat terkait dengan pemenuhan gizi atau konsumsi remaja dalam mengkonsumsi zatzat makanan salah satunya adalah konsumsi zat besi.
Konsumsi yang zat besi yang kurang dapat menimbulkan anemia pada remaja. Pada umumnya, anemia lebih sering terjadi pada wanita dan remaja putri dibandingkan dengan pria. Kebanyakan penderita tidak tahu atau tidak menyadarinya hal ini sangat disayangkan, bahkan ketika tahu pun masih menganggap anemia sebagai masalah sepele (Yusuf, 2011).

Remaja putri memiliki risiko sepuluh kali lebih besar untuk menderita anemia dibandingkan dengan remaja putra. Hal ini dikarenakan remaja putri mengalami menstruasi pada setiap bulannya dan sedang dalam masa pertumbuhan, sehingga membutuhkan lebih banyak asupan gizi. Selain itu, ketidakseimbangan dalam mengkonsumsi zat besi juga merupakan penyebab anemia pada remaja.

Cara mencegah dan menanggulangi kejadian anemia pada remaja diantaranya adalah dengan meningkatkan konsumsi zat besi terutama makanan sumber hewani yang mudah diserap dan juga makanan yang banyak mengandung vitamin $\mathrm{C}$ yang membantu proses penyerapan zat besi serta memberikan suplementasi besi terutama pada saat menstruasi. Peningkatan konsumsi zat besi ini dilakukan dengan berbagai cara diantaranya meningkatkan pengetahuan gizi remaja. Pengetahuan gizi yang baik akan membuat seseorang atau sekelompok masyarakat sadar akanpentingnya gizi bagi kesehatan (Notoatmodjo, 2012).

Pentingnya pemberian zat besi kepada seseorang yang sedang terkena anemia defisiensi besi dan tidak ada

gangguan absorbsi maka dalam $7-10$ hari kadar kenaikan $\mathrm{Hb}$ bisa terjadi dengan mengkonsumsi tablet tambah darah sebesar 1,4 mg/hari (A. Harryanto 
Reksodiputro, 1994). Nilai normal kadar hemoglobin yang paling sering dinyatakan adalah 14-18 $\mathrm{gm} / 100 \mathrm{ml}$ untuk pria dan 12-16 $\mathrm{gm} / 100 \mathrm{ml}$ untuk wanita $(\mathrm{gram} / 100 \mathrm{ml}$ sering disingkat dengan $\mathrm{gm} \%$ atau gr/dl). Beberapa literatur lain menunjukkan nilai yang lebih rendah, terutama pada wanita, sehingga mungkin pasien sering tidak dianggap menderita anemia sampai $\mathrm{Hb}$ kurang dari $13 \mathrm{gr} / 100 \mathrm{ml}$ pada pria dan $11 \mathrm{gr} / 100 \mathrm{ml}$ untuk wanita. Adapun gejala yang sering dialami yaitu lelah, lesu, lemah, letih, lalai, bibir tampak pucat, nafas pendek, lidah licin, denyut nadi meningkat, susah buang air besar, nafsu makan berkurang, kadangkadang pusing, mudah mengantuk (Supariasa dkk, 2012).

Saat ini program pemberian tablet tambah darah bagi remaja kembali di galakkan, target pemberiannya secara nasional adalah $10 \%$ remaja putri mendapatkan tablet tambah darah dengan dosis pencegahan yaitu Remaja putri (10-19 tahun) atau WUS (wanita usia subur) 15-45 tahun sehari 1 tablet selama 10 hari saat menstruasi dan 1 tablet tiap minggunya, jadi total tablet tambah darah $(\mathrm{Fe})$ yang akan diterima oleh remaja putri adalah 13 tablet selama 4 bulan. Fakta di lapangan selama ini tablet tambah darah yang menjadi salah satu alternatif untuk menanggulangi anemia di lapangan hanya masih diberikan kepada ibu hamil saja, dan untuk remaja putri belum maksimal di lakukan, pemberian tablet Fe pada remaja pun masih dilakukan pada sekolah formal seperti SMP dan SMA tetapi belum diberikan pada remaja di pesantren-pesantren. Akibat jangka panjang anemia pada remaja putri yaitu pada saat hamil nanti maka tidak akan mampu memenuhi zat-zat gizi bagi dirinya dan juga janin dalam kandungannya serta dapat meningkatkan frekuensi komplikasi, resiko kematian maternal, angka prematuritas, BBLR, dan angka kematian perinatal, sehingga untuk mencegah kejadian anemia, remaja putri perlu dibekali dengan pengetahuan tentang anemia dan pola asupan makanan remaja itu sendiri (Dharmadi, dkk, 2012).

Kabupaten Tasikmalaya merupakan salah satu kabupaten di Provinsi Jawa Barat yang memerlukan penanggulangan masalah anemia. Berdasarkan hasil survey anemia tahun 2016 diketahui bahwa prevalensi anemia besi pada remaja putri SMP dan SMA adalah 23,2\%, angka ini lebih tinggi dibandingkan dengan angka nasional (Dinas Kesehatan Kab. Tasikmalaya, 2017).

Hasil studi pendahuluan yang dilakukan di Pondok Pesantren Miftahul Khoer Tasikmalaya pada tanggal 21 November 2017 pada remaja putri pada usia 14-20 tahun dari 10 orang remaja setelah dilakukan cek kadar $\mathrm{Hb}$ didapatkan sebanyak 8 orang (80\%) memiliki kadar $\mathrm{Hb}<12$ gr/dl dan sebanyak 2 orang (20\%) memiliki kadar $\mathrm{Hb}>12$ gr/dl.

Berdasarkan uraian diatas, peneliti tertarik untuk melakukan penelitian dengan judul "Pengaruh Pemberian Tablet Fe Terhadap Perubahan Kadar $\mathrm{Hb}$ Pada Remaja putri di Pondok Pesantren Miftahul Khoer Tasikmalaya tahun 2018".

\section{METODE}

Metode penelitian yang dilakukan pada penelitian ini adalah jenis penelitian pre-experimental design, dengan pendekatan pre test (T1) dan post test (T2). Dikatakan pre- 
experimental design, karena desain ini belum merupakan eksperimen sungguh-sungguh. Hal ini dikarenakan masih terdapat variabel luar yang ikut berpengaruh terhadap terbentuknya variabel dependen. Jadi hasil eksperimen yang merupakan variabel dependen itu bukan semata-mata dipengaruhi oleh variabel independen.
Sampel adalah sebagian atau wakil populasi yang di teliti (Arikunto, 2010). Sampel dalam penelitian ini adalah remaja putri di Pondok Pesantren Miftahul Khoer Tasikmalaya tahun 2018 yang mengalami anemia ringan yaitu sebanyak 28 orang.

\section{HASIL PENELITIAN}

Kadar Hb Sebelum dan Sesudah Pemberian Tablet Fe Pada Remaja Putri di Pondok Pesantren Miftahul Khoer Tasikmalaya

\begin{tabular}{llcccc}
\hline \multirow{2}{*}{ No } & \multirow{2}{*}{ Kadar Hb } & \multicolumn{2}{c}{ Sebelum } & \multicolumn{2}{c}{ Sesudah } \\
\cline { 3 - 6 } & & f & \% & f & \% \\
\hline 1 & Tidak Anemia & 0 & 0,0 & 27 & 96,4 \\
2 & Anemia Ringan & 28 & 100 & 1 & 3,6 \\
3 & Anemia Sedang & 0 & 0,0 & 0 & 0,0 \\
4 & Anemia Berat & 0 & 0,0 & 0 & 0,0 \\
\hline \multicolumn{2}{c}{ Jumlah } & $\mathbf{2 8}$ & $\mathbf{1 0 0}$ & $\mathbf{2 8}$ & $\mathbf{1 0 0}$ \\
\hline
\end{tabular}

Tabel di atas menunjukkan bahwa remaja putri di Pondok Pesantren Miftahul Khoer Tasikmalaya sebelum dilakukan pemberian tablet $\mathrm{Fe}$ seluruh remaja mengalami anemia dengan kategori ringan yaitu 28 orang (100\%), sedangkan sesudah dilakukan pemberian tablet $\mathrm{Fe}$ sebagian besar remaja putri tidak mengalami anemia yaitu sebanyak 27 orang $(96,4 \%)$ dan yang mengalami anemia $\begin{array}{lllll}\text { ringan } & \text { sebanyak } & 1 & \text { orang } & (3,6 \%) \text {. }\end{array}$

\section{Pengaruh Pemberian Tablet Fe Terhadap Perubahan Kadar Hb Pada Remaja Putri di Pondok Pesantren Miftahul Khoer Tasikmalaya}

\begin{tabular}{|c|c|c|c|}
\hline \multirow{2}{*}{ No } & \multirow{2}{*}{ Statistik } & \multicolumn{2}{|c|}{ Kadar Hb } \\
\cline { 3 - 4 } & Kadar Hb & Sebelum & Sesudah \\
\hline 1. & Skor Minimal & 11,10 & 11,40 \\
a. & Skor Maksimal & 11,90 & 13,60 \\
b. & Mean & 11,49 & 12,76 \\
c. & Standar Deviasi & 0,273 & 0,489 \\
d. & t-hitung & \multicolumn{2}{|c|}{$-13,031$} \\
\hline e. & $\rho_{\text {value }}$ & \multicolumn{2}{|c|}{0,000} \\
f. & \multicolumn{2}{|c}{} \\
\hline
\end{tabular}


Tabel di atas menunjukkan bahwa kadar $\mathrm{Hb}$ pada remaja putri sebelum dilakukan pemberian tablet $\mathrm{Fe}$ memiliki rerata kadar $\mathrm{Hb}$ sebesar 11,49 dengan standar deviasi 0,273, sedangkan setelah dilakukan pemberian tablet $\mathrm{Fe}$ memiliki skor rerata sebesar 12,76 dan standar deviasi sebesar 0,489. Berdasarkan skor rerata tersebut, maka terjadi peningkatan kadar $\mathrm{Hb}$ pada remaja putri sebelum dan sesudah perlakuan. Hasil uji perubahan kadar $\mathrm{Hb}$ diperoleh nilai t-hitung sebesar 13,031 dengan tingkat signifikansi ( $\rho$ value) sebesar 0,000 , hal ini menunjukkan $\rho$ value kurang dari $\alpha(0,000<0,05)$ yang berarti bahwa ada pengaruh pemberian tablet $\mathrm{Fe}$ terhadap perubahan kadar $\mathrm{Hb}$ pada remaja putri di Pondok Pesantren Miftahul Khoer Tasikmalaya.

\section{E. PEMBAHASAN}

\section{Kadar Hb pada remaja putri usia 14-20 tahun di Pondok Pesantren Miftahul Khoer Tasikmalaya sebelum diberikan tablet Fe.}

Berdasarkan hasil penelitian yang telah dilakukan mengenai kadar $\mathrm{Hb}$ pada remaja putri dengan anemia ringan di Pondok Pesantren Miftahul Khoer sebelum dilakukan pemberian tablet $\mathrm{Fe}$ memiliki rerata kadar $\mathrm{Hb}$ sebesar 11,49. Hal ini sejalan dengan penelitian yang dilakukan oleh Rosi Holida (2017) yang mengatakan bahwa 12 responden $(52,5 \%)$ mengalami anemia ringan, dibandingkan dengan yang tidak anemia sebanyak 9 responden $(39,1 \%)$ dan responden yang mengalami anemia sedang sebanyak 2 responden (8,7\%). Anemia merupakan suatu keadaan dimana kadar hemoglobin dan eritrosit lebih rendah dari normal. Pada perempuan, hemoglobin normal 12$16 \mathrm{gr} \%$ dengan eritrosit $3,5-4,5 \mathrm{jt} / \mathrm{mm}^{3}$ (Depkes 2008).

Anemia yang terjadi pada remaja putri di Pondok Pesantren Miftahul Khoer Tasikmalaya dikarenakan kurangnya asupan nutrisi yang seimbang, karena sebagian besar responden sama-sama memiliki kebiasaan kurang mengkonsumsi makan sumber zat besi sehingga pemenuhan asupan zat besi yang seimbang menjadi kurang.

Menurut Hardinsyah dkk (2007), anemia adalah suatu keadaan kekurangan kadar hemoglobin $(\mathrm{Hb})$ dalam darah yang terutama disebabkan oleh kekurangan zat gizi (khususnya zat besi) yang diperlukan untuk pembentukan $\mathrm{Hb}$. Anemia bukan pencerminan keadaan suatu penyakit atau gangguan fungsi tubuh. Secara fisiologis, anemia terjadi apabila terdapat kekurangan jumlah hemoglobin untuk mengangkut oksigen ke jaringan.

Kebiasaan makan saat remaja dapat mempengaruhi kesehatan pada masa kehidupan berikutnya (setelah dewasa dan berusia lanjut). Kekurangan zat gizi dapat menyebabkan mereka mengalami anemia yang menyebabkan keletihan, sulit konsentrasi sehingga remaja pada usia bekerja menjadi kurang produktif. Remaja membutuhkan lebih banyak zat besi terutama para wanita, karena setiap bulannya mengalami haid yang berdampak kurangnya asupan zat besi dalam darah sebagai pemicu anemia (Istiany \& Rusilanti, 2013).

Sedikit sekali yang diketahui tentang asupan pangan pada remaja, meskipun asupan kalori dan protein sudah tercukupi, elemen lain seperti besi, kalsium, dan beberapa vitamin ternyata masih kurang. Kekurangan zat besi dapat mengakibatkan anemia dan keletihan. Remaja membutuhkan lebih banyak besi dan wanita membutuhkan lebih banyak lagi untuk mengganti besi yang hilang bersamaan dengan darah haid. Anemia pada remaja putri adalah suatu keadaan kadar hemoglobin dalam darah kurang dari normal dengan nilai $\mathrm{Hb}$ normal pada remaja putri menurut WHO adalah 12 gr/dl (Mariana, 2013).

Berdasarkan uraian tersebut, peneliti berpendapat bahwa kejadian anemia pada remaja putri di Pesantren Miftahul Khoer disebabkan kurangnya asupan nutrisi 
(pola dan frekuensi makan) yang tidak seimbang dengan aktivitas kegiatan yang dilakukan di lingkungan pesantren.

\section{Kadar Hb pada remaja putri usia 14-20 tahun di Pondok Pesantren Miftahul Khoer Tasikmalaya setelah diberikan tablet Fe.}

Berdasarkan hasil penelitian yang telah dilakukan mengenai kadar $\mathrm{Hb}$ pada remaja putri dengan anemia ringan di Pondok Pesantren Miftahul Khoer sesudah dilakukan pemberian tablet $\mathrm{Fe}$ memiliki rerata kadar $\mathrm{Hb}$ sebesar 12,76.

Hasil penelitian ini sejalan dengan penelitian Putri Ardhana BE, dkk (2012) yang memberikan intervensi dengan suplementasi $\mathrm{Fe}$ dan Zinc menyatakan bahwa pada kadar $\mathrm{Hb}$ sesudah suplementasi memiliki pengaruh positif terhadap peningkatan kadar $\mathrm{Hb}$. Menurut Haryanto, (2011) pentingnya pemberian zat besi ini kepada seseorang yang sedang mengalami anemia defisiensi besi dan tidak ada gangguan absorpsi maka dalam 7-10 hari kadar kenaikan hemoglobin bisa terjadi sebesar $1,4 \mathrm{mg} / \mathrm{KgBB} /$ hari.

Zat besi merupakan zat yang sangat esensial bagi tubuh. Zat besi sangat berpengaruh dalam peningkatan jumlah eritrosit pada ibu hamil (Kenaikan sirkulasi darah ibu dan kadar hemoglobin atau $\mathrm{Hb}$ ) yang sangat penting guna mencegah terjadinya anemia. Karena jika jumlah konsentrasi eritrosit atau konsentrasi $\mathrm{Hb}$ menurun akan menyebabkan penurunan pada transportasi oksigen dari paru ke jaringan perifer (Waryana, 2010).

Pemberian tablet $\mathrm{Fe}$ pada remaja putri yang mengalami anemia di Pondok Pesantren Miftahul Khoer Tasikmalaya diberikan 1 minggu satu tablet dengan waktu pemberian pada malam hari, tablet $\mathrm{Fe}$ diminum dengan air putih, dengan diberikannya tablet $\mathrm{Fe}$ pada remaja putri yang mengalami anemia dapat meningkatkan kadar $\mathrm{Hb}$, sehingga remaja putri dapat terhindar dari anemia. Sebaiknya remaja mengkonsumsi zat besi sebanyak $26 \mathrm{mg} /$ hari untuk mencukupi kebutuhan zat besinya dan kebutuhan asam folat sebanyak $400 \mathrm{mcg} / \mathrm{hari}$, semakin tinggi asupan protein, vitamin $\mathrm{C}$ dan zat besi semakin tinggi pula kadar hemoglobin remaja (Wartonah, 2010).

Sumber makanan kaya zat besi dan asam folat umumnya terdapat pada sumber protein hewani seperti hati, ikan dan daging yang harganya relatif mahal dan belum sepenuhnya terjangkau oleh kebanyakan masyarakat di Indonesia. Pemberian tablet tambah darah sebagai salah satu upaya penting dalam pencegahan dan penanggulangan anemia yang merupakan cara yang efektif karena dapat mencegah dan menanggulangi anemia akibat kekurangan zat besi dan atau asam folat. Tablet tambah darah merupakan tablet yang diberikan kepada wanita usia subur dan ibu hamil. Bagi wanita usia subur diberikan sebanyak 1 (satu) kali seminggu dan 1 (satu) kali sehari selama haid dan untuk ibu hamil diberikan setiap hari selama masa kehamilannya atau minimal 90 (sembilan puluh) tablet (Permenkes, RI No. 88, 2014).

Berdasarkan hasil penelitian menunjukkan bahwa ada beberapa remaja putri yang mengalami indikasi dari pemberian tablet Fe, seperti mual yang terjadi pada minggu pertama setelah mengkonsumsi tablet $\mathrm{Fe}$, sedangkan feses yang berwarna hitam terjadi pada minggu ke tiga. Hal ini sejalan dengan pendapat Hardjosaputra (2008) yang menjelaskan bahwa efek samping tablet Fe antara lain : 1) Mual muntah, derajat mual yang ditimbulkan oleh setiap preparat bergantung pada jumlah elemen zat besi yang diserap, 2) Nyeri ulu hati, 3) Kram lambung, 4) Konstipasi ataupun diare dan 5) Warna hitam pada feses. 
3. Pengaruh pemberian tablet Fe terhadap perubahan kadar $\mathrm{Hb}$ pada remaja putri usia 14-20 tahun di Pondok Pesantren Miftahul Khoer Tasikmalaya.

Berdasarkan hasil penelitian yang telah dilakukan mengenai pengaruh pemberian tablet Fe terhadap perubahan kadar $\mathrm{Hb}$ pada remaja putri usia 14-20 tahun di Pondok Pesantren Miftahul Khoer Tasikmalaya sebelum dan sesudah dilakukan pemberian Tablet Fe memiliki perbedaan peningkatan kadar $\mathrm{Hb}$, hal ini terbukti bahwa hasil uji statistik memiliki tingkat signifikansi $\rho_{\text {value }}$ kurang dari $\alpha$ $(0,05)$. Hal ini menunjukkan bahwa terdapat pengaruh pemberian tablet $\mathrm{Fe}$ terhadap perubahan kadar $\mathrm{Hb}$ pada remaja putri usia 14-20 tahun di Pondok Pesantren Miftahul Khoer Tasikmalaya.

Hasil penelitian ini sejalan dengan penelitian yang dilakukan oleh Nanik (2010) dengan intervensi yang dilakukan pada responden di pondok pesantren Al-Hidayah Grobogan dengan mengonsumsi tablet Fe bahwa hasil uji statistik menunjukkan terdapat perbedaan kadar $\mathrm{Hb}$ sebelum dan sesudah intervensi pada kelompok perlakuan $(\mathrm{p}=0.000)$.

Saat mengkonsumsi tablet tambah darah tidak diperbolehkan makan atau minum yang mengandung alkohol, teh, kopi atau buah-buahan yang mengandung alkohol seperti durian, tape, nanas, mangga dikarenakan dapat menurunkan penyerapan zat besi dalam tubuh sehingga manfaatnya menjadi berkurang. Untuk mengurangi gejala mual dan muntah waktu yang tepat minum tablet $\mathrm{Fe}$ setelah makan malam atau menjelang tidur (Depkes, 2008).

Pemberian tablet Fe yang diberikan oleh peneliti dapat menghindarkan resiko terjadinya anemia pada remaja putri, penanggulangan anemia pada remaja putri tidak hanya dilakukan dengan memberikan tablet Fe saja, tetapi juga memberikan pendidikan kesehatan kepada remaja putri tentang pentingnya asupan nutrisi dan pola makan yang baik kepada remaja putri. Pemberian $\mathrm{Fe}$ yang diberikan remaja putri hanya diberikan $1 \mathrm{x}$ dalam seminggu, namun demikian ada perubahan yang signifikan terhadap remaja putri yang mengalami anemia. Studi Februhartanty menyatakan terdapat peningkatan kadar $\mathrm{Hb}$ yang lebih tinggi pada subjek yang diberi suplementasi besi secara mingguan $\quad(1,34 \pm 1,21 \quad \mathrm{~g} / \mathrm{dl})$ dibandingkan dengan menstruasi $(0,35 \pm 0,45 \mathrm{~g} / \mathrm{dl})$. Hasil studi tersebut menunjukkan bahwa suplementasi besi secara mingguan secara signifikan dapat meningkatkan status besi pada remaja putri dengan meningkatnya kadar hemoglobin secara signifikan.

Salah satu upaya yang telah dilakukan pemerintah untuk menanggulangi masalah anemia pada remaja adalah melalui pemberian suplemen tablet tambah darah (TTD) berupa zat besi (60 mg FeSO4 ) dan asam folat $(0,25 \mathrm{mg})$. WHO telah merekomendasikan konsumsi tablet besi untuk Wanita Usia Subur (WUS) menstruasi adalah secara intermittent (1 kali/minggu), dengan dosis TTD 60 $\mathrm{mg}$ elemental besi dan $2,8 \mathrm{mg}$ asam folat selama $12 \mathrm{minggu} / 3$ bulan dengan jeda tiga bulan. Jadi suplementasi diberikan dua kali setahun selama tiga bulan, sehingga jumlah total tablet yang diberikan selama suplementasi adalah 24 tablet/tahun (WHO 2011). Akan tetapi saat ini Kemenkes telah menetapkan dosis suplementasi besi pada WUS (termasuk remaja) adalah 1 tablet/minggu dan ketika menstruasi diberikan setiap hari selama 10 hari dengan lama pemberian empat bulan. Dengan demikian, jumlah total tablet yang diberikan selama suplementasi adalah 52 tablet/tahun dengan TTD yang tersedia sama dengan ibu hamil (Susanti, 2016). 
Berdasarkan uraian tersebut, peneliti berpendapat bahwa pemberian tablet $\mathrm{Fe}$ pada remaja putri yang mengalami anemia ringan dapat meningkatkan kadar $\mathrm{Hb}$.

\section{F. SIMPULAN DAN SARAN}

\section{Simpulan}

Remaja puteri di Pondok Pesantren Miftahul Khoer Tasikmalaya sebelum diberikan tablet Fe termasuk anemia ringan sebanyak 28 orang dengan Kadar $\mathrm{Hb}$ rerata sebesar 11,49. Remaja puteri di Pondok Pesantren Miftahul Khoer Tasikmalaya sesudah diberikan tablet $\mathrm{Fe}$ termasuk tidak anemiasebanyak 27 orang dengan Kadar $\mathrm{Hb}$ rerata sebesar 12,76.Data inimenunjukkanbahwa ada pengaruh pemberian tablet $\mathrm{Fe}$ terhadap perubahan kadar $\mathrm{Hb}$ pada remaja putri di Pondok Pesantren Miftahul Khoer Tasikmalaya, terbukti dengan $\rho_{\text {value }}$ kurang dari $\alpha(0,000<0,05)$.

\section{Saran}

Bagi Remaja, dapat dijadikan sebagai sumber informasi dan pengetahuan mengenai anemia sehingga dapat mencegah terjadinya anemia dengan mengkonsumsi makanan yang mengandung zat besi sebagai kebutuhan tubuh.Bagi Puskesmas, hendaknya petugas kesehatan dapat memberikan pendidikan kesehatan dan sosialisasi Tablet $\mathrm{Fe}$ pada remaja mengenai anemia serta melakukan pendekatan dengan pihak pesantren untuk pemantauan kadar $\mathrm{Hb}$ pada remaja putri setiap 6 bulan sekali. Selain itu, pihak puskesmas mulai melibatkan pihak pesantren untuk menerapkan program pemberian tablet $\mathrm{Fe}$ pada remaja, sehingga sasaran pencapaian target tercapai.Bagi Tenaga Kesehatan, hendaknya penelitian ini dapat dijadikan sebagai acuan dalam memberikan pendidikan kesehatan dalam upaya pencegahan terjadinya anemia pada remaja serta dapat mensosialiasikan pemberian tablet Fe.

\section{G. REFERENSI}

Almatsier, S. 2010. Prinsip Dasar Ilmu Gizi. Jakarta : Gramedia Pustaka Utama.

Arikunto, S. 2010. Prosedur penelitian : Suatu Pendekatan Praktik. (Edisi Revisi). Jakarta : Rineka Cipta.

Arisman. 2004. Gizi dalam Daur Kehidupan: Buku Ajar Ilmu Gizi. Buku Kedokteran. EGC: Jakarta.

Azwar, S. 2009. Sikap Manusia, Teori dan Pengukurannya. Jakarta : Pustaka Pelajar.

Booth, Michael L, \& Okely, Anthony D. 2006. APARQ (Adolscent Physical Activity Recall Questionare). University Sydney : NSW.

Caesarina Ancah. 2009. Kespro Remaja, disampaikan pada Seminar Nasional Seksualitas dan Kesehatan Reproduksi Remaja di PP. Nuris. Juni 2009. Jember-Jawa Timur.

Depkes. RI. 2005. Profil Kesehatan Indonesia. Jakarta: Kementerian Kesehatan RI. . 2008. Program Gizi Makro. Jakarta: Direktorat Gizi Masyarakat Depkes.

Dharmadi, M. dkk. 2012. Penyuluhan Anemia Defisiensi Besi (ADB) Pada Remaja Putri di Sekolah Menengah Atas Negeri 1 Bangli. Terdapat dalam http://www.communityhealthy.com/ 
Handayani, W dan Haribowo, A.S 2008. Buku Ajar Asuhan Keperawatan pada Klien dengan Gangguan Sistem Hematologi. Salemba medika: Jakarta.

Hardiansyah. 2007. Review Faktor Determinan Keragamam Asupan Pangan. Fakultas Ekologi Manusia. Institut Pertanian Bogor. Jurnal Gizi Dan Pangan.

Hardjosaputra, S.L., dkk. 2008. Data Obat di Indonesia. Cetakan: PT. Nusantara Lestari Ceriapratama. Jakarta: PT. Muliapurna Jaya

Jordan, S. 2004. Farmakologi

Kebidanan. Jakarta : EGC

Karim, Faizati. 2002. Panduan Kesehatan Olahraga Bagi Petugas Kesehatan. Jakarta: Tim Departemen Kesehatan.

Kemenkes RI. 2013. Riset Kesehatan Dasar. Jakarta: Badan Penelitian dan pengembangan Kesehatan Kementrian Kesehatan RI.

Kirana. 2011. Hubungan Asupan Zat Gizi dan Pola Menstruasi Dengan Kejadian Anemia Pada Remaja Putri. Artikel penelitian. Universitas Diponegoro.

Kusmiran, E. 2011. Kesehatan Reproduksi Remaja Dan Wanita. Jakarta: Salemba Medika.

Manuaba, IBG., 2010. IlmuKebidanan, penyakitKandungandan $\quad K B$ untukPendidikanBidan.Edisi 2. Jakarta: EGC

Mukhatib MD. 2009. Problem Kesehatan Reproduksi Remaja: Tawaran Solusi, disampaikan pada Seminar Nasional Seksualitas dan Kesehatan Reproduksi Remaja di PP. Nuris, Juni 2009. Jember-Jawa Timur.
Nanik Kristyan. 2010. Perbedaan Kadar Hemoglobin Sebelum Dan Setelah Pemberian Tablet Besi (Fe) pada Santri Putri di Pondok Pesantren Al-Hidayah Kabupaten Grobogan. Jurusan Ilmu Kesehatan Masyarakat, Fakultas Ilmu Keolahragaan, Universitas Negeri Semarang.

Notoatmodjo, S. 2012. Promosi kesehatan dan Perilaku Kesehatan. Jakarta. Rineka cipta.

Peraturan Menteri Kesehatan Republik Indonesia Nomor 88 Tahun 2014 Tentang Standar Tablet Tambah Darah Bagi Wanita Usia Subur Dan Ibu Hamil.

Proverawati, Atikah. 2011. Anemia dan Anemia kehamilan. Yogyakarta : Nuha Medika

Sediaoetama. 2010. Ilmu Gizi. Jakarta: Dian Rakyat.

Setiadi. 2007. Konsep dan Penulisan Riset Keperawatan. Yogyakarta: Graha Ilmu

Soetjiningsih. 2012. Perkembangan Anak dan Permasalahannya dalam Buku Ajar I Ilmu Perkembangan Anak Dan Remaja. Jakarta : Sagungseto.

Sugiyono. 2010. Metode penelitian Kuantitatif Kualitatif dan $R \& D$. Penerbit Alfabeta.

Sukmadinata, Nana Syaodih. 2011. Metode Penelitian Pendidikan. Bandung: PT Remaja Rosdakarya.

Supariasa. 2012. Pendidikan Dan Konsultasi Gizi. Jakarta : EGC

Susanti, Yeti. 2016. Pengaruh Pemberian Suplemen Besi Terhadap Kadar Hemoglobin dan Tingkat 
Kelelahan pada Remaja Putri. Institut

Pertanian Bogor.

Wartonah, Tarwoto. 2010. Kebutuhan Dasar manusia dan Proses

Keperawatan. Jakarta. Salemba Medika.

Widyastuti, Yani dkk. 2009. Kesehatan Reproduksi. Yogyakarta : Fitramaya.

Wiknjosastro H. 2009. Ilmu Kebidanan. Edisi ke-4 Cetakan ke-2. Jakarta: Yayasan Bina Pustaka Sarwono Prawirohardjo.

Yusuf, Syamsu. 2011. Psikologi Perkembangan Anak dan Remaja. Bandung : PT Remaja Rosdakarya. 